\title{
Examining Ethical Leadership and Its Impacts on the Followers' Behavioral Outcomes
}

\author{
Hamed Khakssar Ghahroodi ${ }^{1}$, Mohd Zulkifli bin Tan Sri Mohd Ghazali ${ }^{1} \&$ Zahra Seyed Ghorban ${ }^{2}$ \\ ${ }^{1}$ International Business School, UTM, Malaysia \\ ${ }^{2}$ Department of Marketing, Monash University, Australia \\ Correspondence: Hamed Khakssar Ghahroodi, International Business School, UTM, Malaysia. E-mail: \\ hamed_kh@hotmail.com
}

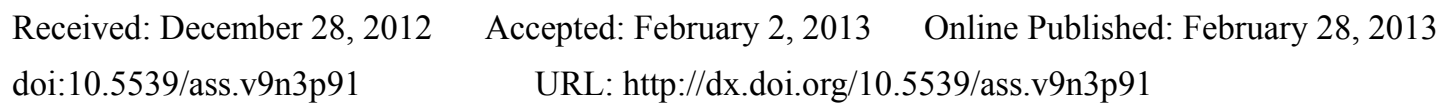

\begin{abstract}
Recently introduced and conceptualized ethical leadership was examined in one sector of hospitality industry in this study. Scholars believe that by becoming role models in terms of conducting ethical codes of conducts in behaviors and decision making-process, leaders are able to enhance and influence different outcomes in their respective organization. To empirically examining the productive influence of this particular leadership, employee's behavioral outcomes were investigated. Using 117 data revealed that when leaders are considered to be role models in their respective organizations, their followers tend to be satisfied and committed, in which would result in diminishing their intention to leave the organizations.
\end{abstract}

Keywords: ethical leadership, job satisfaction, affective commitment, turnover intention

\section{Introduction}

Studying leadership has been an interesting area of investigation among scholars for a century. Different definitions and implications have been proposed and substantiated for this respective discipline. One of the recent expansions of leadership has been the introduction of ethical leadership (Brown, Treviño, \& Harrison, 2005), which has become an interesting subject among academics. They believe that this might be attributed to the current ethical scandals in organizations that calls for ethical behaviors and conduction in organizations (Brown et al., 2005; Mehta, 2003; Revell, 2003)

Despite its recent introduction and conceptualization (Brown et al., 2005), ethical leadership has been able to attract relatively a great deal of attentions from both researchers and practitioners. Some have investigated this type of leadership in service industry (Ruiz-Palomino, Ruiz-Amaya, \& Knörr, 2011), while others have tried to study this leadership differently (Walumbwa et al., 2011). But there is still a gap to investigate and validate this type of leadership in different industries and in various contexts to establish the universal acceptance, which would lead to its successful adoption in organizations in the way to provide them with enhanced outcomes.

Scholars have found significant relationship between ethical leadership and different organizational outcomes. Ruiz-Palomino, et al. (2011) have found that there exists significant relationship between supervisors' ethical leadership and employees affective commitment and job satisfaction, which consequently result in citizenship behavior among those employees in banking industry. Mayer, Kuenzi, Greenbaum, Bardes, and Salvador (2009), by studying different kinds of organizations in the U.S. found that the top managers' ethical leadership is positively related to supervisory ethical leadership, which in turn both of managers ethical leadership and supervisory ethical leadership is positively related to group organizational citizenship behavior (OCB).

Despite interesting and sophisticated attention by researchers to study ethical leadership in different kinds of organization, little attention has been paid to hospitality industries with the exception of what Kim and Brymer (2011) have done in hotel industry in the U.S. They found that ethical leadership is positively related to both job satisfaction and affective commitment. In their empirical investigation, there are indications for the positive impact of both job satisfaction and affective commitment on turnover intention, which in turn influences the competitive performance in organizations. Further investigation in hospitality industry is seriously felt and it is required to thoroughly understand how this particular industry could be benefited by applying ethical leadership model in its top and middle level managers, since some have argued that the "leadership" term has currently 
become impressively appropriate in this industry due to the hard hit hospitality industry are experiencing by economic downturn and intense decline in travel utilization (Kim \& Brymer, 2011).

Therefore, it is the main objective of the current study to examine the ethical leadership model in a comparatively different geographical location by focusing on travel agencies as one of the sectors in the hospitality industry. The central attention is toward empirically examining the relationship of ethical leadership with those outcomes such as job satisfaction and commitment among middle managers and how their level of turnover intention would be diminished.

\section{Background and Hypotheses}

Studying how leaders' role is important in forming ethical conducts in organizations and society has gained importance since there have been ethical misconducts and scandals in business (Brown et al., 2005; Colvin, 2003; Mehta, 2003). Brown, et al. (2005) believed that in order to shape such ethical conducts in organizations leaders are the central source. These scholars as the originator of new stream of research in ethical leadership have argued regarding the previous ethical dimensions in leadership and mentioned, "previous study of an ethical dimension of leadership has been embedded primarily within the transformational and charismatic leadership domains". They argued that others, while studying different theories and styles of leadership, have not fully covered and addressed ethical issues in leadership, which called for further investigation. They considered ethical leadership as a social learning perspective in which it proposes that leaders by being a role model influence the ethical conduct of their followers.

Consequently, they mentioned, “... leaders become attractive, credible, and legitimate as ethical role models in part by engaging in ongoing behaviors that are evaluated by followers as normatively appropriate, and that suggest altruistic (rather than selfish) motivations. Such behaviors include honesty, consideration of others and fair treatment of employees (including respect and voice)". Therefore, it could be inferred that ethical leadership is conceptualized in terms of social learning in which ethical leaders are considered role models of ethical behaviors.

Ethical leadership is, then, defined as "the demonstration of normatively appropriate conduct through personal actions and interpersonal relationships, and the promotion of such conduct to followers through two-way communication, reinforcement, and decision-making" (Brown et al., 2005, p. 120).

Job satisfaction has been an interesting variable in social science (Bowling, Beehr, \& Lepisto, 2006) and has been studied in many ways (Lam, Zhang, \& Baum, 2001). While Ivancevich and Donnelly (1968) (as cited in Lam et al., 2001) discussed that most of scholars and researchers defined job satisfaction in their own ways, but there have been proposed definitions for this concept. Locke (1969) has defined job satisfaction as " $a$ pleasurable or positive emotional stable resulting from the appraisal of one's job as achieving or facilitating one's job value. Job dissatisfaction is the unpleasurable emotional state resulting from the appraisal of one's job as frustrating or blocking the attainment of one's value". (p. 317).

Another increasing area of investigation in social science has been studying organizational commitment. Becker (1960) believed that "when a person makes a side bet he/she come in to being committed". It could be inferred that an individual when making a bet, whether ought to, needs to, or wants to, has to continue his/her bet and become engaged with what he/she has bet for. Mowday et al. (1982), as one of the pioneers in studying organizational commitment comprehensively, defined it as "the relative strength of how an individual identifies $\mathrm{him} /$ herself with an organization and how much he/she involves in an organization". It could be inferred that being committed to an organization would mean that one identifies him/herself with that organization, feels attached to it, and how much he/she is willing to involve and participate.

Allen and Meyer (1990) defined three constructs for organizational commitment as "affective", "continuance", and "normative" commitment. Affective commitment is regarded as the most widespread form of organizational commitment (Allen \& Meyer, 1990; Meyer \& Allen, 1987). This sense of commitment would be considered as one being emotionally and effectively attached to his/her organization and identifies him/herself with it while enjoying his/her membership in the respective organization. Affective commitment, among others, is the primary focus of this research.

Studying turnover intention has been shown to be important in organizational setting especially in hospitality industry since it is regarded as one of the most worrying matters (Ghiselli, La Lopa, \& Bai, 2001). Reviewing the relevant literature in the hospitality industry demonstrate that studying turnover intention, its antecedents, and consequences needs further investigation since the number of studies are limited (Kim \& Brymer, 2011). Scholars discussed that the related costs to employees turnover in hospitality business would be tremendous 
(Hinkin \& Tracey, 2000; Tracey \& Hinkin, 2008). Higher turnover intention would lead to higher recruitment and replacement costs (Deery \& Iverson, 1996; Manley, 1996). While turnover intention in hospitality industry lacks sufficient literature, especially in non-western countries, this study is going to bring more in-depth of how it could diminished among middle managers by establishing and improving their level job satisfaction and affective commitment.

Brown, et al. (2005), in their theory of ethical leadership , suggest that ethical leaders' role in enhancing the attitudes and behaviors of their respective followers and employees are important. It has been substantiated that the relationship between ethical leadership and employees job satisfaction is significant and consequently these employees (followers) would show higher job satisfaction with their work when their leaders are ethical (Brown et al., 2005). Findings from the hospitality industry also indicate that the relationship between ethical leadership and followers' job satisfaction in positive and significant (Kim \& Brymer, 2011). Therefore, this study hypothesize that:

Hypothesis 1: The ethical leadership of executives is positively correlated to their middle managers' job satisfaction.

The relationship between ethical leadership and subordinates' organizational commitment has been shown to be significant (Brown \& Treviño, 2006). Empirical studies have also demonstrated the relationship between ethical leadership and affective organizational commitment in the hospitality industry (Kim \& Brymer, 2011). Therefore, this study hypothesize that:

Hypothesis 2: The ethical leadership of executives is positively correlated to their middle managers' affective organizational commitment.

While job satisfaction among employees has been indicated as a key predictor of employee turnover (Williams \& Hazer, 1986), it has been demonstrated that the stronger the level of satisfaction among the employees, the lower their intention for turnover would be (Shaw, 1999). The negative relationship between middle managers' job satisfaction and their intention for turnover has been demonstrated (Kim \& Brymer, 2011) therefore, this study hypothesize that:

Hypothesis 3: Middle managers' job satisfaction is negatively correlated to their turnover intention.

On the other hand, organizational commitment has also been showed to be negatively related to employee turnover intention (Colbert \& Kwon, 2000). This relationship has also been examined in the hospitality industry and results indicate the negative association (Kim \& Brymer, 2011). Therefore, this study hypothesize that:

Hypothesis 4: Middle managers' affective organizational commitment is negatively correlated to their turnover intention.

\section{Methodology}

\subsection{Study sample}

This study concentrated on examining the above-mentioned hypotheses in the hospitality industry in Malaysia, which has become an interesting destination for many tourists around the globe and has been able to attract almost 25 million people (Tourism Malaysia, 2012). Tourism industry provided almost 2 million jobs in 2010 for the country contributing about $16 \%$ share of employment (UFTAA, 2012). Based on the information provided in the MATTA website (Malaysian Association of Tour and Travel Agents), this association started with 30 members and today there are more than 2800 members including tour and travel organizations in the country (MATTA, 2012). Time and budget constraints would not allow to examine this number of agencies, therefore, only the tour and travel agencies located in the city of Kuala Lumpur were focused for the purpose of data collection in the current study. 200 questionnaires were distributed among middle managers in this particular sector in the hospitality industry, out of which 117 usable data were received.

\subsection{Instruments}

The instruments that have been used in prior researches and proved to be valid and reliable in what they measure examined the four variables included in this study. To measure ethical leadership 10 items developed by Brown et al. (2005) were used. Job satisfaction was measured using 4 items that examined in Babakus, Yavas, Karatepe, and Avci (2003). Meyer and Allen's (1991) 8 items were used to measure affective commitment. To measure turnover intention 3 items from Karatepe and Uludag (2008) were used. All the instruments were ranked based on 7-point Likert Scale in which 1 equals to Strongly Disagree and 7 equals to Strongly Agree. 


\section{Results}

One of the most well known tests to measure the reliability status of measurement instruments in a research is "Cronbach's Alpha". This test is used extensively in research to establish the reliability of instruments used. The purpose of performing this test is to examine the accuracy of an instrument to measure what it is meant to measure. This test reveals "accurateness" and "precision" of a particular instrument. Different criteria have been proposed for the level of reliability in this test, but Nunnally (1978) suggested that the reliability level above 0.60 is regarded as a satisfactory level for a particular instrument in a research. Table 1 presents the results for the reliability status for all the variables in this study. This concludes that the reliability statuses for all the variables are satisfactory.

Table 1. Reliability analysis

\begin{tabular}{lccc}
\hline Variable & No. & $\alpha$ & Status \\
\hline Ethical Leadership & 10 & 0.86 & Reliable \\
Job Satisfaction & 4 & 0.92 & Reliable \\
Affective Commitment & 8 & 0.96 & Reliable \\
Turnover Intention & 3 & 0.84 & Reliable
\end{tabular}

Note: $\mathrm{N}=117$

Table 2 presents the means, the standard deviation, and the results obtained from the correlation analysis. As shown, all the correlations reached the significance level at $\mathrm{p}<0.01$.

Table 2. Mean, standard deviation, and the correlation analysis

\begin{tabular}{lcccccc}
\hline Variable & Mean & SD & 1 & 2 & 3 & 4 \\
\hline 1. Ethical Leadership & 5.45 & 1.25 & 1 & & & \\
2. Job Satisfaction & 5.35 & 1.43 & $0.52^{* *}$ & 1 & & \\
3. Affective Commitment & 5.34 & 1.33 & $0.71^{* *}$ & $0.65^{* *}$ & 1 & \\
4. Turnover Intention & 2.79 & 1.58 & $-0.76^{* *}$ & $-0.62^{* *}$ & $-0.69^{* *}$ & 1 \\
\hline
\end{tabular}

Note: $\mathrm{N}=117 ;{ }^{* *}$ Correlation is significant at the 0.01 (two-tailed)

Regression analysis using SPSS 19.0 package from IBM conducted to test the proposed hypotheses and the results are presented in table 3. As shown, ethical leadership was found to be positively and significantly related to both job satisfaction and affective commitment supporting hypotheses 1 and 2. Both job satisfaction and affective commitment found to be negatively and significantly related to turnover intention, which provided support for hypotheses 3 and 4 .

Table 3. Testing hypotheses

\begin{tabular}{llccccc}
\hline & Hypotheses & $\mathrm{R}^{2}$ & $\Delta \mathrm{R}^{2}$ & $\beta$ & $\mathrm{t}$-value & Sig \\
\hline 1. Ethical Leadership & Job Satisfaction (+) & 0.38 & 0.37 & 0.62 & 8.37 & .000 \\
2. Ethical Leadership & Affective Commitment (+) & 0.47 & 0.46 & 0.69 & 10.12 & .000 \\
3. Job Satisfaction & Turnover Intention (-) & 0.42 & 0.41 & -0.65 & -9.04 & .000 \\
4. Affective Commitment $\quad$ Turnover Intention (-) & 0.51 & 0.50 & -0.71 & -10.81 & .000
\end{tabular}

\section{Discussions}

This study set out to address the issue of "Ethical Leadership" in one sector of the hospitality industry in Malaysia. This emerging leadership style (Brown et al., 2005) has been receiving attentions from scholars in different contexts (e.g. Martin, Resick, Keating, \& Dickson, 2009; Neubert, Carlson, Kacmar, Roberts, \& Chonko, 2009; Ruiz-Palomino et al., 2011; Walumbwa et al., 2011), while hospitality industry has received little 
attention on how this particular types of leading followers would be able to improve outcomes among employees. On the other hand, this study attended to the relationships between the ethical leadership, job satisfaction, and affective organizational commitment, and how they would be related to turnover intention.

The current research by targeting the above-mentioned gap in the hospitality industry in general and in travel agencies in particular has provided several insights for both ethical leadership and hospitality industry literature. First, this study has expanded the research on ethical leadership and extended it to a new context, while enriching the respective literature. Second, consistent with previous findings, the empirical analysis in the current research confirmed the positive association of ethical leadership with followers' behavioral attitudes such as their job satisfaction and affective commitment (Brown et al., 2005; Neubert et al., 2009; Ruiz-Palomino et al., 2011). This indicates that leaders namely superiors and executives in organizations would be able to enhance these outcomes by becoming a role model in terms of following ethical behaviors and conducting decision-making procedures based on ethical standards.

Third, the findings of this study, in line with previous results (e.g. Colbert \& Kwon, 2000; Kim \& Brymer, 2011; Shaw, 1999), suggest that the relationship of both job satisfaction and affective commitment with turnover intention is negative. This implies that when followers become satisfied (happy with what they do) and committed (enjoy the membership in organizations), their intention to leave the organization would be diminished. Leaders should realize that having satisfied and committed employees that would result in their intention to leave to be reduced will assist them to avoid any associated costs such as recruitments, trainings, etc.

This study while focusing on ethical leadership could only investigate job satisfaction and organizational commitment as the outcome variables of this leadership style. The literatures suggest that leadership is able to enhance various outcomes both among followers and in organizations. Future research needs to be conducted to investigate how ethical leadership could predict other outcomes. The current research could only cover one sector of hospitality industry as tour and travel agencies. Future investigations could expand the model to other sectors of hospitality industry to find out how becoming a role model in term of being ethical in behaviors and decision-making would help leaders to improve such outcomes among their followers.

\section{References}

Allen, \& Meyer. (1990). The measurement and antecedents of affective, continuance and normative commitment to the organization. Journal of Occupational Psychology, 63(1), 1-18. http://dx.doi.org/10.1111/j.2044-8325.1990.tb00506.x

Babakus, E., Yavas, U., Karatepe, O. M., \& Avci, T. (2003). The Effect of Management Commitment to Service Quality on Employees' Affective and Performance Outcomes. Journal of the Academy of Marketing Science, 31(3), 272-286. http://dx.doi.org/10.1177/0092070303031003005

Becker, H. S. (1960). Notes on the concept of commitment. American Journal of Sociology, 66, 32-42. http://dx.doi.org/10.1086/222820

Bowling, N. A., Beehr, T. A., \& Lepisto, L. R. (2006). Beyond job satisfaction: A five-year prospective analysis of the dispositional approach to work attitudes. Journal of Vocational Behavior, 69(2), 315-330. http://dx.doi.org/10.1016/j.jvb.2006.04.004

Brown, M. E., \& Treviño, L. K. (2006). Ethical leadership: A review and future directions. The Leadership Quarterly, 17(6), 595-616. http://dx.doi.org/10.1016/j.leaqua.2006.10.004

Brown, M. E., Treviño, L. K., \& Harrison, D. A. (2005). Ethical leadership: A social learning perspective for construct development and testing. Organizational Behavior and Human Decision Processes, 97(2), 117-134. http://dx.doi.org/10.1016/j.obhdp.2005.03.002

Colbert, A. E., \& Kwon, I. G. (2000). Factors related to the organizational commitment of college and university auditors. Journal of Management Issues, 11(4), 484-502.

Colvin, G. (2003). Corporate crooks are not all created equal. Fortune, October(27), 64.

Deery, M. A., \& Iverson, R. D. (1996). Enhancing productivity: intervention strategies for employee turnover. In N. Johns (Ed.), Productivity Management in Hospitality and Tourism. London: Cassell.

Ghiselli, R. F., La Lopa, J. M., \& Bai, B. (2001). Job Satisfaction, Life Satisfaction, and Turnover Intent. Cornell Hotel and Restaurant Administration Quarterly, 42(2), 28-37.

Hinkin, T. R., \& Tracey, J. B. (2000). The cost of turnover: Putting a price on the learning curve. Cornell Hotel and Restaurant Quarterly, June, 14-21. http://dx.doi.org/10.1177/001088040004100313

Karatepe, O. M., \& Uludag, O. (2008). Affectivity, conflicts in the work, Äifamily interface, and hotel employee 
outcomes. International Journal of Hospitality Management, $27(1), \quad 30-41$. http://dx.doi.org/10.1016/j.ijhm.2007.07.001

Kim, W. G., \& Brymer, R. A. (2011). The effects of ethical leadership on manager job satisfaction, commitment, behavioral outcomes, and firm performance. International Journal of Hospitality Management, 30(4), 1020-1026. http://dx.doi.org/10.1016/j.ijhm.2011.03.008

Lam, T., Zhang, H., \& Baum, T. (2001). An investigation of employees, Äô job satisfaction: the case of hotels in Hong Kong. Tourism Management, 22(2), 157-165. http://dx.doi.org/10.1016/S0261-5177(00)00039-X

Locke, E. A. (1969). What is job satisfaction? Organizational Behavior and Human Performance, 4, $309-336$. http://dx.doi.org/10.1016/0030-5073(69)90013-0

Manley, H. (1996). Hospitality head hunting. Australian Hotelier, April, 8-11.

Martin, G. S., Resick, C. J., Keating, M. A., \& Dickson, M. W. (2009). Ethical leadership across cultures: a comparative analysis of German and US perspectives. Business Ethics: A European Review, 18(2), $127-144$. http://dx.doi.org/10.1111/j.1467-8608.2009.01553.x

MATTA. (2012). About MATTA. Retrieved $20 \quad$ July, 2012, from http:/www.matta.org.my/index.php/about-matta/introduction

Mayer, D. M., Kuenzi, M., Greenbaum, R., Bardes, M., \& Salvador, R. (2009). How low does ethical leadership flow? Test of a trickle-down model. Organizational Behavior and Human Decision Processes, 108(1), 1-13. http://dx.doi.org/10.1016/j.obhdp.2008.04.002

Mehta, S. (2003). MCI: Is being good good enough? Fortune, 27, 117-124.

Meyer, J. P., \& Allen, N. J. (1987). Organizational commitment: Toward a three-component model. Research Bulletin. The University of Western Ontario, Department of Psychology, London, 660.

Meyer, J. P., \& Allen, N. J. (1991). A three component conceptualization of organization commitment. Human Resource Management Review, 1(1), 61-89. http://dx.doi.org/10.1016/1053-4822(91)90011-Z

Mowday, R. T., Porter, W. L., \& Steers, R. M. (1982). Employee- organization linkages: The psychological of commitment, absenteeism and turnover. New York, NY: Academic Press.

Neubert, M., Carlson, D. S., Kacmar, K. M., Roberts, J., \& Chonko, L. B. (2009). The virtuous influence of ethical leadership behavior: evidence from the field. Journal of Business Ethics, 90(2), 157-170. http://dx.doi.org/10.1007/s10551-009-0037-9

Revell, J. (2003). The Wres that won't go out. Fortune, 13, 139.

Ruiz-Palomino, P., Ruiz-Amaya, C., \& Knörr, H. (2011). Employee Organizational Citizenship Behaviour: The Direct and Indirect Impact of Ethical Leadership. Canadian Journal of Administrative Sciences / Revue Canadienne des Sciences de l'Administration, 28(3), 244-258. http://dx.doi.org/10.1002/cjas.221

Shaw, J. D. (1999). Job satisfaction and turnover intentions: the moderating role of positive affect. The Journal of Social Psychology, 139(2), 242-244. http://dx.doi.org/10.1080/00224549909598378

Tourism Malaysia. (2012). Tourism arrivals and receipts to Malaysia. Retrieved 20 July, 2012, from http://corporate.tourism.gov.my/research.asp?page=facts_figures

Tracey, J. B., \& Hinkin, T. R. (2008). Contextual factors and cost profiles associated with employee turnover. Cornell Hotel \& Restaurant Administration Quarterly, 49(1), 12-27.

UFTAA. (2012). Malaysia: Increase in Tourist Arrivals in 2012. Retrieved 20 July, 2012, from http:/www.uftaa.org/index.php?option=com_content\&view=article\&id=408:malaysia-increase-in-tourist-ar rivals-in-2012\&catid $=42$ : headlines

Walumbwa, F. O., Mayer, D. M., Wang, P., Wang, H., Workman, K., \& Christensen, A. L. (2011). Linking ethical leadership to employee performance: The roles of leader,Äìmember exchange, self-efficacy, and organizational identification. Organizational Behavior and Human Decision Processes, 115(2), $204-213$. http://dx.doi.org/10.1016/j.obhdp.2010.11.002

Williams, L., \& Hazer, J. (1986). Antecedents and consequences of satisfaction and commitment in turnover models: a re-analysis using latent variable structural equation models. Journal of Applied Psychology, 71, 219-231. http://dx.doi.org/10.1037/0021-9010.71.2.219 